\title{
Rediscovery and description of the cubomedusa Alatina grandis (Agassiz \& Mayer, 1902) (Cnidaria: Cubozoa: Alatinidae) from Pakistani waters
}

\author{
IlKa Straehler-Pohl ${ }^{1, *} \&$ ShahnaWAZ Gul ${ }^{2}$ \\ ${ }^{1}$ Medusa(')s Nursery, Private Laboratory for Life cycle, Developmental and Evolutionary Research, Altmarkstr. 25, 21684 Stade- \\ Hagen, Germany \\ ${ }^{2}$ Department of Zoology, Jamia Millia Government Degree College, Malir, Karachi, Pakistan
}

Received 26 October 2015; Accepted 29 September 2016 Responsible Editor: Dhugal Lindsay

\begin{abstract}
In 2014, a huge sized box jellyfish specimen was caught during a fishing trawl in off-shore waters near Karachi, Pakistan. While taking photographs the specimen broke into pieces due to its own weight but at least its size hinted to its identity as a member of one of three Carybdeida families: Alatinidae Gershwin, 2005 (genera Alatina Gershwin, 2005 or Keesingia Gershwin, 2014), Carukiidae Bentlage et al., 2010 (genus Morbakka Gershwin, 2008) or Tamoyidae Haeckel, 1880 (genus Tamoya Müller, 1859). After sampling six more specimens off Sonmiani, Pakistan, morphological observation of the diagnostic features was possible and all these specimens were identified to belong to the family Alatinidae, precisely the genus Alatina. There are only 7 accepted Alatina species but up to now only one possesses a bell size this big.

This report presents the occurrence of the alatiniid jellyfish, Alatina grandis (Agassiz \& Mayer, 1902), officially recorded for the first time from waters off the coast of Pakistan in the northern Arabian Sea and the rediscovery of specimens from this region in the collection of the 'John Murray' Expedition 1933-34 of the Natural History Museum in London.
\end{abstract}

Key words: Alatina alata, Alatina rainensis, box jellyfish, cubomedusae, new records

\section{Introduction}

Cubozoans are a small group of jellyfish, containing between 40 and 50 species (Bentlage \& Lewis 2012, Kingsford \& Mooney 2014), that inhabits mostly warmer coastal areas (Kingsford et al. 2012). This group is well known because of the high toxicity of most species (Williamson et al. 1996, Yanagihara et al. 2002, Carrette et al. 2002, 2012, Carette \& Seymour 2004, 2005, 2006, 2013, Bordehore et al. 2011, 2014) that has caused several fatalities (Williamson et al. 1996, http://thaiboxjellyfish.blogspot. de). But besides this, the group also presents other interesting aspects, like courtship (Lewis \& Long 2005, Lewis et al. 2008, Straehler-Pohl et al. 2014, Garm et al. 2012, 2015, Chiaverano et al. 2013, Canepa et al. 2014, Carrette et al. 2014), vision (Coates 2003, Nordström et al. 2003, Nilsson et al. 2005, Garm et al. 2006, 2007a+b, 2008, Garm \&

*Corresponding author: Ilka Straehler-Pohl; E-mail, i.straehler-pohl@ web.de
Bielecki 2008) and taxonomic classification (Bigelow 1938, Werner 1973, Gershwin 2005b, 2006, Bentlage et al. 2010, Straehler-Pohl 2014, Toshino et al. 2013, 2015). Also the validity of some species, especially the ones of the alatinid family, has been discussed since the beginning of the last century (Mayer 1910, Bigelow 1938, Kramp 1961, Gershwin 2005a, b, Bentlage 2010, Bentlage et al. 2010, Lewis et al. 2013). This is because some species were never officially seen again after their first description and the type material got lost, as in the cases of Alatina alata (Reynaud, 1830), Alatina turricula (Haeckel, 1880), Alatina philippina (Haeckel, 1880), Alatina tetraptera (Haeckel, 1880) and Alatina madraspatana (Menon, 1930) or because the type material is in such bad shape, as in the case of Alatina grandis (Agassiz \& Mayer, 1902), that their validity is hard to prove (Bentlage 2010).

Our goal here is to add to the knowledge of cubozoans from Pakistani waters and to the knowledge of the distribution of the rare cubozoan species, A. grandis: we provide the first official records of this alatiniid species off 
the coast of Pakistan in the northern Arabian Sea, in the central Arabian Sea, in the Gulf of Oman and off Kameran, Red Sea, by sampled live specimens and rediscovered specimens in the collection of the 'John Murray' Expedition 1933-34 of the Natural History Museum in London.

\section{Materials and methods}

\section{Pakistani specimens}

The specimens were collected as by-catch during fishing activities in the northern Arabian Sea along the Pakistani coast. One specimen was collected on 02 March 2014 from the waters off Karachi $\left(24^{\circ} 51^{\prime} 41.264^{\prime \prime} \mathrm{N}, 67^{\circ} 0^{\prime} 35.779^{\prime \prime} \mathrm{E}\right)$ and photographed but not retained, while six specimens were collected on 05 March 2015 from off Sonmiani $\left(25^{\circ} 25^{\prime} 21.873^{\prime \prime} \mathrm{N}, 66^{\circ} 35^{\prime} 53.864^{\prime \prime} \mathrm{E}\right)$ and preserved in $7 \%$ formaldehyde-seawater. Detailed examination and photographs of different morphological features of the preserved specimens were taken in the laboratories of the Department of Zoology, Jamia Milla Government Degree College Malir, Karachi, Pakistan. The voucher specimens are deposited in the Museum of the Department of Zoology (JMGDC MDZ CN 22).

Registered and unregistered preserved material of different alatinid species was inspected directly in the collections of the relevant museums or institutes (see list of preserved examined material below).

The type material of Alatina grandis and Keesingia gigas Gershwin, 2014 were not available during this study, therefore, literature was used for comparison (Agassiz \& Mayer 1902, Mayer 1910, 1917, 1928, Bentlage 2010, Gershwin 2014).

\section{Preserved Material Examined}

\section{Alatinid species:}

\section{Alatina grandis:}

United Kingdom: British Natural History Museum (BNHM), London: 1 specimen (BNHM1983.4.25.2) from the Philippines labelled as Tamoya alata, and 3 specimens (BNHM 1950.3.25.1, 1950.3.25.2, 1950.3.25.3) from the 'John Murray Expedition' 193334 from the Arabian Sea and adjacent seas, labelled as Tamoya alata.

\section{Alatina alata:}

Australia: Queensland Museum (QM), Brisbane, Queensland: 1 specimen (QM G55228), labelled as Alatina mordens.

Belgium: Royal Belgium Institute of Natural Science (RBINS), Brussels: 1 specimen (RBINS I.G.9223) from India, labelled as Tamoya alata; 2 unregistered specimens, from Papua-New Guinea, labelled as Carybdea alata.
Spain: Institut de Ciències del Mar (CSIC), Barcelona: 1 specimen, (AFRICANA PHYLLOSOMA SURVEY:002006(1))

Alatina rainensis Gershwin, 2005

Australia: Queensland Museum (QM), Brisbane, Queensland: 2 mature specimens (holotype QMG55286, paratype QMG55287).

\section{Measurements}

Standard measurements were used (Straehler-Pohl 2014): bell height (BH) as length between bell turn-over (velarium excluded from measurement) and top of apex; interpedalial diameter (IPD) as distance between opposite pedalia (outer pedalial wing edges) at the level of the bell turn-over; we also measured pedalia length (PL) from attachment to bell to the tentacle insertion as the proportion in relation to bell height.

\section{Photos, original drawings}

Photographs of anatomical details of Alatina grandis (London collection), Alatina alata and Alatina rainensis were taken with digital cameras (Canon Powershot G12 and Canon Eos 550D).

The photos of the Sonmiani specimens were taken with a Fujifilm JZ100 camera. Fig. 1A was provided by Muhammad Moazzam Khan.

The original drawings of Alatina grandis by Agassiz \& Mayer (1902) were used with courtesy from the collections of the Ernst Mayr Library, Museum of Comparative Zoology, Harvard University.

\section{"Gonads" in Cubozoa}

Campbell (1974: 142) stated that "gonads" in most cnidarians are not separate organs, as found in higher animals, because germ cells are generally found in interstitial portions of the body tissue which, prior to the formation of germ cells, exhibit no reproductive specialization. However, we follow Campbell (1974), Marques \& Collins (2004), Bentlage et al. (2010), Morandini \& Marques (2010) and Straehler-Pohl \& Toshino (2015) in using the term gonad to refer to areas where gametes are formed.

\section{Results}

The classification of the species Alatina grandis and others used in this study for comparison, is shown in Table 1.

In March 2014, a very large carybdeida specimen (Fig. 1A) with a bell height of $180 \mathrm{~mm}$ and a bell width of $114 \mathrm{~mm}$ (IPD) was sampled during a fishing excursion in offshore waters, off Karachi in the Northern Arabian Sea. Unfortunately, the specimen broke in half due to its own weight when the habitus was photographed. The animal was discarded after taking the photographs and the later identification was based on six other specimens, with a bell height of up to $220 \mathrm{~mm}$, that were sampled off Sonmiani 


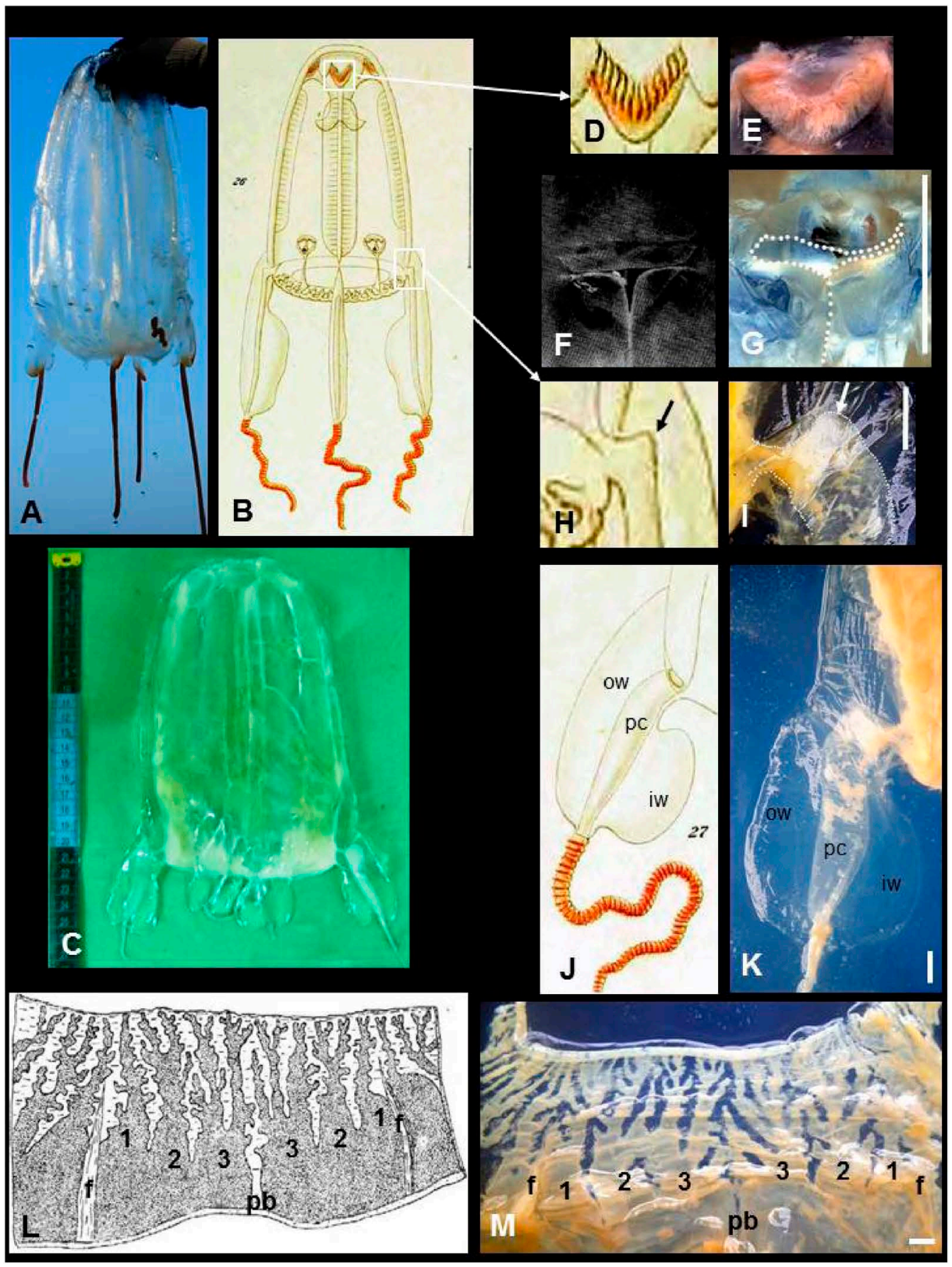

Fig. 1. Comparison of photos of Pakistani specimens with original drawings of Alatina grandis by Agassiz \& Mayer (1902: Figs. 26, 27; with courtesy from the collections of the Ernst Mayr Library, Museum of Comparative Zoology, Harvard University) and images of a specimen from the Red Sea identified as Charybdea alata by Stiasny (1939: Figs. 2, 4): A: habitus of living Karachi specimen (image provided by M. Moazzam Khan); B: habitus of juvenile Alatina grandis, drawing by Agassiz \& Mayer (1902: Fig. 26); C: preserved Sonmiani specimen; D: gastric phacellus of A. grandis, drawing by Agassiz \& Mayer (1902: Fig. 4); E: gastric phacellus of Sonmiani specimen; F: rhopalial niche opening, note "T"-shape with 3 covering scales, photo by Stiasny (1939: Fig. 2); G: rhopalial niche opening of Sonmiani specimen; H: pedalial canal knee bend (arrow), drawing by Agassiz \& Mayer (1902: close up of Fig. 26); I: pedalial canal knee bend (arrow) of Sonmiani specimen; J: pedalium with pedalial canal, drawing of pedalium of adult specimen by Agassiz \& Mayer (1902: Fig. 27); K: pedalium with pedalial canal of Sonmiani specimen; L: Velarium of "Charybdea alata”, canal roots are marked by numbers, drawing by Stiasny (1939: Fig. 4); M: velarium of Sonmiani specimen, canal roots are marked by numbers. f: frenulum; iw: inner pedalial wing; ow: outer pedalial wing; pb: pedalial base level; pc: pedalial canal. 
Table 1. Recent classification of the species of the order Carybdeida with highlighted species in bold used in this study for comparison (following Gershwin 2005b, 2014, Bentlage et al. 2010, Bentlage \& Lewis 2012, Lewis et al., 2013).

Phylum Cnidaria Verrill, 1865

Subphylum Medusozoa Petersen, 1979

Class Scyphozoa Werner, 1973

Subclass Discomedusae Haeckel, 1880

Order Cubomedusae Haeckel, 1880

Suborder Carybdeida Lesson, 1843

Family Alatinidae Gershwin, 2005

Genus Alatina Gershwin, 2005

Alatina alata (Reynaud, 1830)

$=$ ? Alatina obeliscus (Haeckel, 1880)

= Alatina moseri (Mayer, 1906)

(=Alatina mordens Gershwin, 2005)

Alatina grandis (Agassiz \& Mayer, 1902)

Alatina madraspatana (Menon, 1930)

Alatina morandinii (Straehler-Pohl \& Jarms, 2011)

?Alatina pyramis (Haeckel, 1880)

Alatina rainensis Gershwin, 2005

Alatina tetraptera (Haeckel, 1880)

Genus Keesingia Gershwin, 2014

Keesingia gigas Gershwin, 2014

Genus Manokia Southcott, 1967

Manokia stiasnyi (Bigelow, 1938)

Family Carukiidae Bentlage, Cartwright, Yanagihara, Lewis, Richards \& Collins, 2010

Genus Carukia Southcott, 1967

Carukia barnesi Southcott, 1967

Carukia shinju Gershwin, 2007

Genus Gerongia Gershwin \& Alderslade, 2005

Gerongia rifkinae Gershwin \& Alderslade, 2005

Genus Malo Gershwin, 2005

Malo bella Gershwin, 2014

Malo filippina Bentlage \& Lewis, 2012

Malo maxima Gershwin, 2005

Genus Morbakka Gershwin, 2008

Morbakka fenneri Gershwin, 2008

Morbakka virulenta (Kishinouye, 1910)

Family Carybdeidae (Lesson, 1843)

Genus Carybdea Péron \& Lesueur, 1810

Carybdea arborifera Maas, 1897

Carybdea branchi Gershwin \& Gibbons, 2009

Carybdea brevipedalia Kishinouye, 1891

(=Carybdea mora Kishinouye, 1910)

Carybdea marsupialis (Linnaeus, 1758)

Carybdea murrayana Haeckel, 1880

Carybdea rastonii Haacke, 1887

Carybdea xaymacana Conant, 1897

Family Tamoyidae Haeckel, 1880

Genus Tamoya F. Müller, 1859

Tomoya haeckeli Southcott, 1967

Tamoya haplonema F. Müller, 1859

Tamoya ohboya Collins, Bentlage, Gillan, Lynn, Morandini \& Marques, 2011

?Tamoya prismatica Haeckel, 1880

Family Tripedaliidae Conant, 1897

Genus Copula Bentlage, Cartwright, Yanagihara, Lewis, Richards \& Collins, 2010 Copula sivickisi (Stiasny, 1926)

Genus Tripedalia Conant, 1897

Tripedalia binata Moore, 1988

Tripedalia cystophora Conant, 1897 
and preserved for inspection in March 2015 (Fig. 1C).

\section{Discussion}

\section{Taxonomic history}

In October 1899, during the expedition of the Steamer "Albatross" to the tropical Pacific 1899-1900 (Bowers 1909), a single specimen of a huge carybdeida medusa was found in an open net that had been towed from a depth of 300 fathoms $(550 \mathrm{~m})$ to the surface, south of Fakarava Island, Paumotus (French Polynesia) (Agassiz \& Mayer 1902). The next day a large swarm of mature individuals of the same species was discovered floating very near the surface of the sea off Anaa Island. The specimens reached a bell height of $230 \mathrm{~mm}$. Agassiz and Mayer (1902) described these specimens as a new species, Charybdea grandis. Mayer (1910) corrected the name to Carybdea grandis. Mayer $(1917,1928)$ reported two more sampling locations of Carybdea grandis in the Philippines (Luzon) and in Malaysia (Borneo), collected during the "Albatross" Expedition. Those specimens were immature and reached bell heights of only 120 and $167 \mathrm{~mm}$, respectively.

Since 1909, no official sightings of Carybdea grandis were published until Williamson et al. (1996: pp. 241-243, Plate 9.10) described a sighting by Loisette Marsh from the Western Australian Museum, who took an image of a huge specimen of approx. $500 \mathrm{~mm}$ bell height from the coast of Western Australia, suggesting that it belonged to this species. About 20 years later, this suggestion was corrected by Gershwin (2014) who described it as a new genus and species, Keesingia gigas.

Stiasny $(1937,1939)$ described carybdeida specimens of enormous bell heights $(\geq 240 \mathrm{~mm})$ and with alatiniid characters (Stiasny 1937: Fig. 2: rhopalial niche opening "T"shaped; 1939: Fig. 1: habitus, Fig. 2: rhopalial niche opening " $T$ "-shaped) from the "John Murray Expedition to the Arabian Sea, 1933-34" and from the collection of Dr. J. H. Ziesel from Kamaran (south end of Red Sea); he described these specimens as Tamoya alata or Charybdea alata, respectively, and listed Charybdea alata var. grandis as a synonym (Stiasny 1937: 210).

Gershwin (2005b) established the new family Alatinidae and the new genus Alatina in which she placed all species that were formerly identified as Carybdea alata and which showed crescentic phacellae, " $\mathrm{T}$ "-shaped rhopalial niche openings, large pedalial wings and a velarial pattern that showed 6 or 8 velarial canals per quadrant. She renamed Carybdea grandis to Alatina grandis, even if the type material seemed to be lost.

Bentlage (2010) discovered the thought-to-be-lost type material of Alatina grandis in the collection of the National Museum of Natural History in Washington. It was one of the specimens caught off Anaa Island and was still labelled with the handwriting of A. G. Mayer (Bentlage 2010).

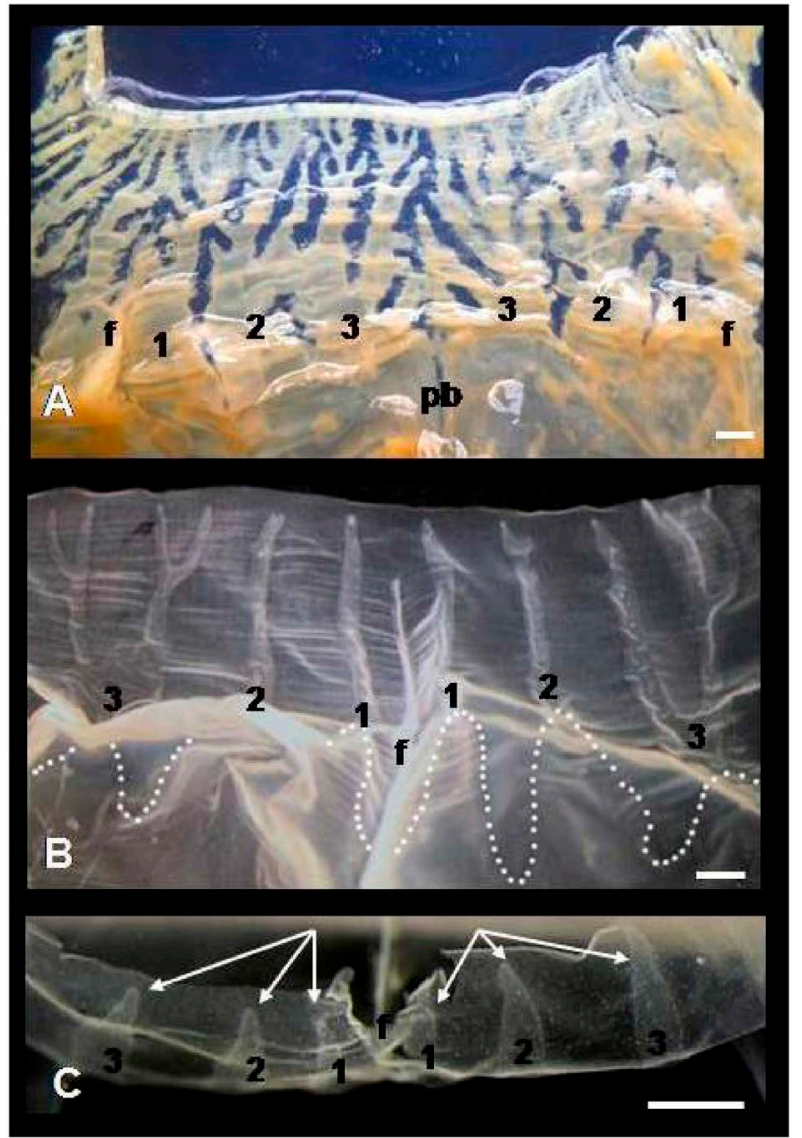

Fig. 2. Velarial structures of different alatinid species, i.e. Alatina grandis (A: Sonmiani specimen), Alatina alata (QM G55228) (B), Alatina rainensis (holotype QMG55286) (C): A: quadrant of velarium, note 3 velarial canal roots per octant, canals complexly branched, canal margins jagged; B: quadrant of velarium, note 3 velarial canal roots per octant, canals simple to forked, canal margins smooth (dotted line marks velarial lappets); C: quadrant of velarium, note 3 velarial canal roots per octant, canals simple triangular (arrows), canal margins smooth. f: frenulum; pb: pedalial base.

\section{Comparison to other alatinids with a short and concise delineation from other large Carybdeida}

In March 2014, a very large carybdeida specimen (Fig. 1A) with a bell height of $180 \mathrm{~mm}$ and a bell width of $114 \mathrm{~mm}$ (IPD) was sampled during a fishing excursion in offshore waters, off Karachi in the Northern Arabian Sea. As the specimen broke in half when the habitus was photographed, the later identification was based on six other specimens with a bell height of up to $220 \mathrm{~mm}$ that were sampled off Sonmiani and preserved for inspection in March 2015 (Fig. 1C).

The enormous size of the bell of the Karachi specimen reduced the identification options to 3 carybdeida families and to one or two species within each family, as the bell height in all those species is up to $160 \mathrm{~mm}$ or more-Carukiidae: Morbakka fenneri with a bell height of up to $180 \mathrm{~mm}$ (Fenner et al. 1985, Fenner 1986, Gershwin 2008), 


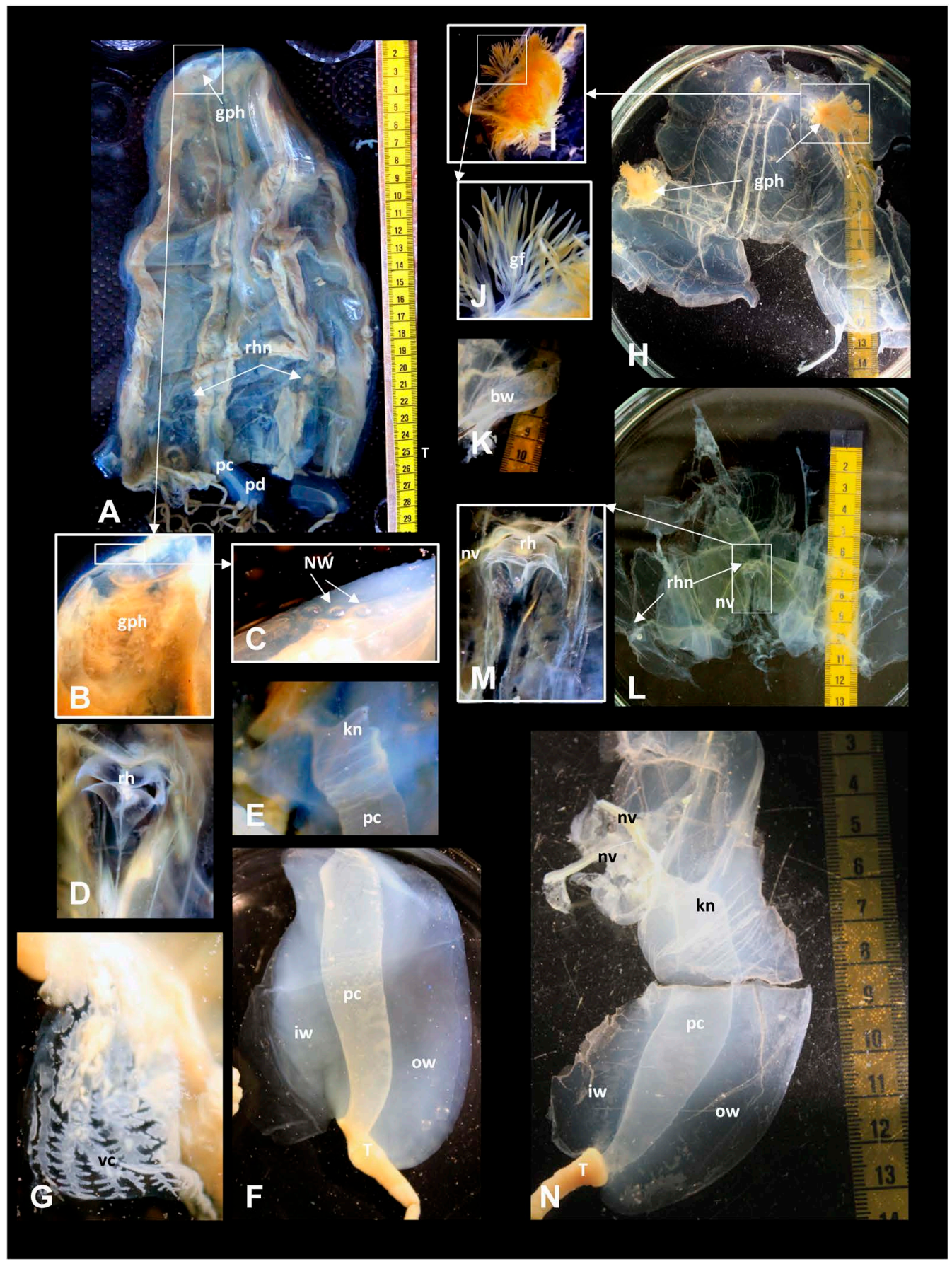

Fig. 3. Images of rediscovered specimens from the Arabian Sea and the Gulf of Oman identified as Tamoya alata by Stiasny (1937: p. 210-210, Figs. 1, 2) found in the 'John Murray Expedition' collection in the Natural History Museum in London: A: habitus of Arabian Sea (St. 43) specimen; B: Part of Apex containing crescent-shaped gastric phacellum; C: Nematocyst warts on Apex (white arrows); D: Rhopalial niche with 'T'-shaped opening, covering scales so large that they close the opening nearly completely; E: rectangular knee bend of upper pedalial canal; F: pedalium with pedalial canal, note that inner and outer wing overhang tentacle insertion; G: velarial canals; H: broken upper part and apex of Gulf of Oman (St. 65) specimen; I: crescent-shaped gastric phacellum; J: dendritic, brush-shaped gastric filament; K: body wall, note thickness of mesogloea (8-12 mm); L: broken lower part of Gulf of Oman (St. 65) specimen including rhopalial niches and pedalial bases; M: rhopalial niche with 'T'-shaped opening; N: broken pedalium with pedalial canal, note enormous length of pedalium (95 mm) hinting to a body length of probably $400 \mathrm{~mm}$ or more. bw: body wall; gf: gastric filament; gph: gastric phacellum; iw: inner pedalial wing; ow: outer pedalial wing; kn: pedalial knee bend; nv: nerve; NW: nematocyst warts; pd: pedalium; pc: pedalial canal; rh: rhopalium; rhn: rhopalial niche; T: tentacle; vc: velarial canal. 
Morbakka virulenta with a bell height of up to $250 \mathrm{~mm}$ (Toshino et al. 2013); Tamoyidae: Tamoya haplonema with a bell height of up to $165 \mathrm{~mm}$ (Haeckel 1880, pers. observation) and Alatinidae: Alatina grandis with a bell height of up to $240 \mathrm{~mm}$ (Agassiz \& Mayer 1902, Mayer 1910, 1917, 1928, Stiasny 1937) or Keesingia gigas with a bell height in the immature holotype of $190 \mathrm{~mm}$ and of ca. $500 \mathrm{~mm}$ in an unregistered specimen (Williamson et al. 1996, Gershwin 2014).

All those carybdeida species are very similar at first sight (large higher-than-wide bell covered with prominent nematocyst warts, long, broad, and simple pedalia with unbranched tentacles, broad velarium with complexly patterned velarial canals; Figs. 1L, M, 2A, B, C, 3A, F).

As crescentic gastric phacellae (Fig. 1D) and a shallow, small stomach were noted in the Sonmiani specimens (Fig. 1E), they could be identified as members of the family Alatinidae. Therefore, the Morbakka species, as members of the family Carukiidae which are characterized by the lack of gastric phacellae or filaments in their large stomachs (Gershwin 2008, Bentlage et al. 2010, Bentlage \& Lewis 2012, Straehler-Pohl 2014), and members of the family Tamoyidae, which possess gastric phacellae that are arranged in vertical lines along the inner wall of a huge balloon-like stomach (Müller 1859, Bigelow 1938: Figs. 17, 18), could definitely be excluded from the list of possible identities.

Keesingia gigas possesses the necessary bell size to qualify it for comparison with the Sonmiani specimens. However, the " $\mathrm{T}$ "-shaped rhopalial niche openings of the Sonmiani specimens possess clearly separated lower covering scales, the cleft between them running down the bell until reaching the bell turnover, while the lower covering scales of $K$. gigas are only partly separated, the cleft measuring only a few millimetres (Gershwin 2014: Fig. 2A). Also, the velarial canal system of the Sonmiani specimens is very different from that of $K$. gigas, which possesses, according to Gershwin (2014), 5 velarial canal roots per octant, splitting into 6-9 "feather-like" velarial canals per octant, while the Sonmiani specimens bear 3 velarial canal roots per octant which give rise to 1 to 3 velarial canals each, showing a broad, non-"feather-like" structure. Next to that and contrary to most other known species of the order Carybdeida, both pedalial wings of $K$. gigas are notably warty without aberration after sampling (Gershwin 2014) while the pedalia of Alatina grandis and the Sonmiani specimens are smooth and definitely have no warts on the inner wings. Therefore, Keesingia gigas could also be excluded from the list of possible identities.

The " $T$ "-shaped rhopalial niches, with clearly separated lower covering scales, defined the Sonmiani specimens to be a member of either the genus Manokia or the genus Alatina. Manokia styasnii could be ruled out, because as well as Manokia's small size $(23 \mathrm{~mm})$ and the egg-like shape of its body, it has branched tentacles (Stiasny 1930, Gershwin 2005b) and the Sonmiani specimens possessed smooth, fi- liform, non-branched tentacles. Therefore, the specimens from the Arabian Sea had to be members of the genus Alatina.

At present, there is no mature medusa specimen of Alatina morandinii available for examination, which would disqualify this species for comparison, but nontheless, the body size of this species is still very small $(8 \mathrm{~mm})$ when the development of gonads starts (Straehler-Pohl \& Toshino 2015), too small to be conspecific with the Sonmiani material. The following species of the genus Alatina could also be excluded due to their peculiar body shapes or small body size in mature specimens: Alatina madraspatana, Alatina pyramis, Alatina tetraptera (Menon 1930, Haeckel 1880: Plate 25, Figs. 3, 5, 1904: Plate 78, Fig. 7).

The remaining Alatina species could be excluded due to differences in the velarial canal structures. Alatina obeliscus (Haeckel 1904: Plate 78, Fig. 3), Alatina alata (Fig. 2B) and Alatina rainensis (Fig. 2C) show simple to bifurcated velarial canals with smooth margins while the velarial canal structure of the Sonmiani specimens is complexly branched and the canal margins are jagged (Figs. 1M, 2A). Unfortunately, Agassiz \& Mayer (1902) drew only the habitus and the structure of velarial canals of a juvenile Alatina grandis specimen and Bentlage (2010) stated that the number of velarial canals and their shape could not be determined due to the poor condition of the type specimen. The structure, therefore, cannot be compared here, though the number of velarial canal roots is clearly 3 per octant (Agassiz \& Mayer 1902) like in the Sonmiani specimens. The gastric phacellae and tentacles of Alatina grandis and the Sonmiani specimens are notably pinkish to yellowish pink in colour (Figs. 1A, B, C, D, I, 2C; Agassiz \& Mayer 1902: Figs. 26, 27) in life and when newly preserved. Alatina grandis possesses pedalial canals with a volcanoshaped pedalial knee bend with a blunt, rounded top (Fig. $1 \mathrm{H})$ and the canals are flared at the proximal end and taper towards the distal end (Agassiz \& Mayer 1902: Fig. 26; present study: Fig. 1J; Bentlage 2010: Fig. 1B) identical to the ones found in the Sonmiani specimens (Figs. 1I, K). Therefore, and also because of the body size, we conclude that the specimens from Karachi and Sonmiani must be identified as Alatina grandis (Agassiz \& Mayer, 1902).

\section{Commentary on "Tamoya alata/Charybdea alata" from the Gulf of Oman and the Red Sea}

The velarial canal system of our Sonmiani specimens resemble closely those reported by Stiasny (1937: Fig. 1; 1939: Fig. 4; present study: Fig. 1K) of specimens with bell heights up to $240 \mathrm{~mm}$ from the Arabian Sea, the Gulf of Oman or the Red Sea identified by him first as Tamoya alata and later as Charybdea alata with Charybdea alata var. grandis as a synonym. Three (3) of the specimens described and figured by Stiasny (1937) were rediscovered in the 'John Murray Expedition' collection of the British Natural History Museum in London (Figs. 4, 5). As all three were in the same condition as Stiasny (1937) described 


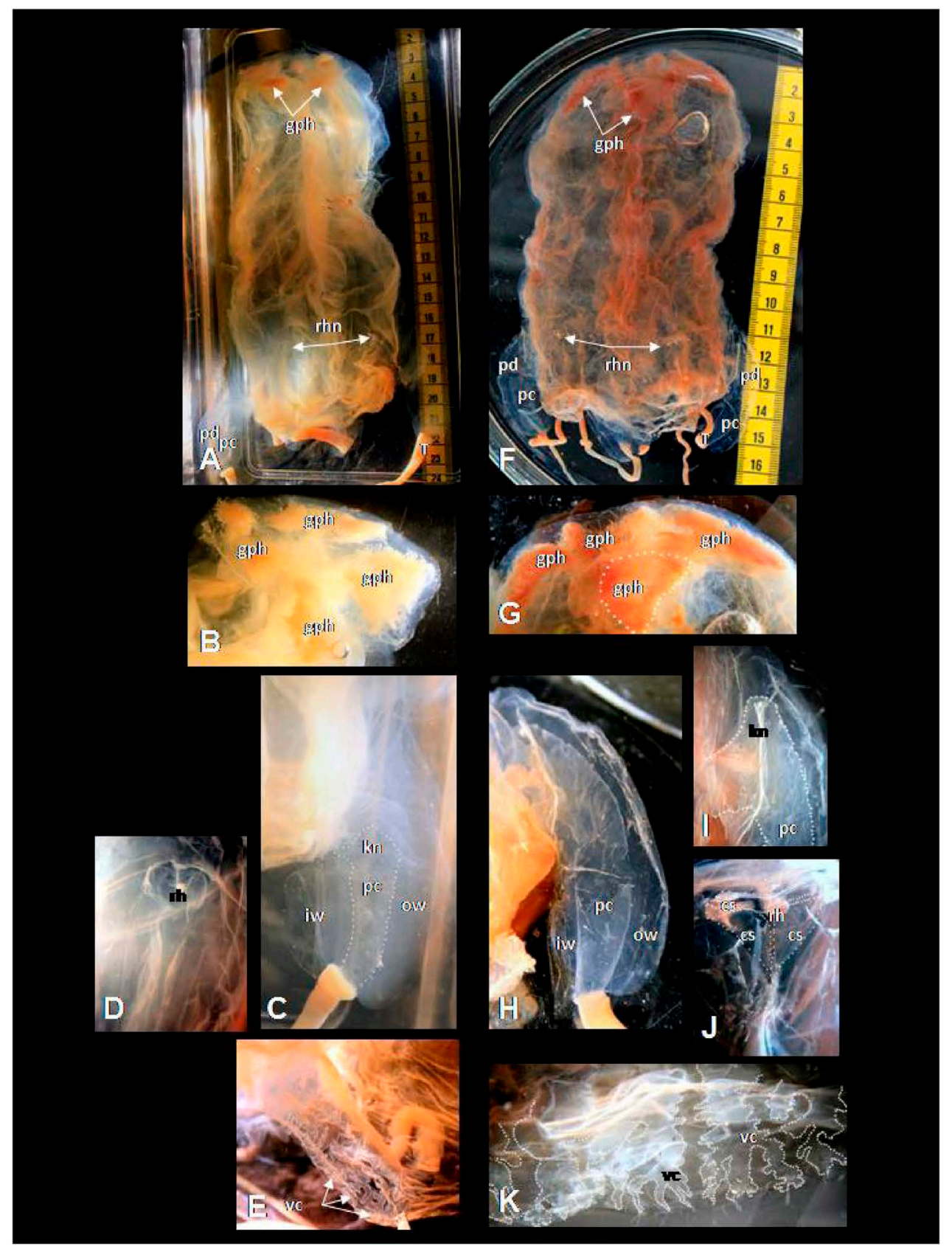

Fig. 4. Images of the rediscovered specimen from the central Arabian Sea identified as Tamoya alata by Stiasny (1937: p. 210-210) found in the 'John Murray Expedition' collection in the Natural History Museum in London and one specimen from the Philippine Islands, also identified as Tamoya alata: A: habitus of central Arabian Sea (St. 95) specimen; B: apex containing crescent-shaped gastric phacellae; C: pedalium with pedalial canal (marked by dotted line), note dome-shaped pedalial knee bend ; D: rhopalial niche with 'T'-shaped opening; E: velarium with velarial canals; F: habitus of Philippine Islands specimen; G: apex containing crescent-shaped gastric phacellae (marked by dotted line); H: pedalium with pedalial canal; I: volcano-shaped pedalial knee bend (marked by dotted line); J: rhopalial niche with 'T'-shaped opening; K: velarium with velarial canals (marked by dotted line); cs: covering scale; gph: gastric phacellum; iw: inner pedalial wing; ow: outer pedalial wing; kn: pedalial knee bend; pd: pedalium; pc: pedalial canal; rh: rhopalium; rhn: rhopalial niche; T: tentacle; vc: velarial canal.

them, it was possible to take images of all characteristic features and compare them to our Sonmiani specimens directly. These specimens and the one described, figured and photographed by Stiasny (1939) showed, in every aspect, features identical to those of our Sonmiani speci- mens and are therefore considered the same species, being hereby identified as Alatina grandis (Mayer \& Agassiz, 1902). The distribution of this species ranges from the $\mathrm{Pa}-$ cific Ocean to the Indian Ocean and might be circumtropical like the species Alatina alata, which has been found 
in the Pacific (Hawaii, Australia, New Guinea) (Lewis et al. 2013, Carrette et al. 2014, specimens inspected for this study), in the western and south eastern Atlantic (Pagès et al. 1992, Collins et al. 2011, specimen inspected for this study) and the Indian Ocean (specimen from India inspected for this study).

\section{Commentary on "Carybdea marsupialis" from Gwadar, Pakistan}

In 2006, Kazmi \& Sultana (2008) sampled carybdeida specimens from Gwadar, Pakistan (Arabian Sea), which they identified as Carybdea marsupialis (Linnaeus, 1758). However, due to their huge bell sizes $(150-190 \mathrm{~mm} \mathrm{BH}$ and up to $95-120 \mathrm{~mm}$ in width) and the velarial canal structure, Gul et al. (2015) and Acevedo et al. (in review) doubted their identification as Carybdea marsupialis, because that species reaches a bell height of only about $40 \mathrm{~mm}$ and a bell width of about $40 \mathrm{~mm}$ (quotient: $\geq 1: 1$; Gueroun et al. 2015, Acevedo et al., in review).

In particular, the structure of the velarial canals shown in Kazmi \& Sultana (2008: Fig. 2) is identical to that of our Alatina grandis specimens from Sonmiani (Fig. 1L) and to the ones of Stiasny (1937: Fig. 1; 1939: Fig. 4; present study: Fig. 1K). Furthermore, the shapes of the pedalia and pedalial canals (Kazmi \& Sultana 2008: Fig. 2) are identical to the ones shown in our specimens (Fig. 1J), the one in Bentlage (2010: Fig. 1B) and the one drawn by Agassiz \& Mayer (1902: Figs. 27, 29; Figs. 2A, B). Furthermore, the body size of the Gwadar specimens reported by Kazmi \& Sultana (2008) is in the range of the specimens reported by us and by Stiasny (1937: 175 to $\geq 240 \mathrm{~mm} \mathrm{BH;} \mathrm{1939:}$ $120 \mathrm{~mm} \mathrm{BH}$ ). The body quotient of IPD/BH is 0.63 , nearly identical to the one apparent in Alatina grandis. Therefore, we conclude that the Gwadar specimens are more likely to be members of the family Alatinidae than of the family Carybdeidae and, because of their huge sizes, body quotient, the shapes of their pedalia, pedalial canals and velarial canals and their sampling location, we conclude that these specimens should also be identified as Alatina grandis (Agassiz \& Mayer, 1902).

Due to the new data provided in this study a detailed species description is provided below:

\section{Species description of Alatina grandis based on Sonmi- ani specimens}

\section{Alatina grandis (Agassiz \& Mayer, 1902)}

Synonyms:

Alatina grandis: Gershwin 2005a: x (table of contents), 102 (revised classification list), 144 (remarks to Alatina moseri), 147 (discussion about being synonym to Alatina turricula; description of species), 151 (species list table), 152 (in discussion of Alatina clade), Plate 5.5 Figs. B, C, 170 (taxonomic changes table); Gershwin 2005b: 514 (Fig. 5 B, C), 515 (remarks to Alatina moseri), 516 (discussion about being synonym to Alatina turricula; description of species), 520 (in discussion of Alatina clade); Bentlage 2010: 52-53 (throughout, Fig. 1);
Carybdea alata: Cornelius 1997: 122, 123 (species description, plate: drawing of medusa and rhopalial niche);

Carybdea alata auct.: Bentlage 2010: 52 (title)

"Carybdea alata in der Form grandis": Krumbach 1925: 570 (body size comparisons).

Carybdea alata var. grandis: Mayer 1910: III (table of contents), 511-512 (species description); Mayer 1915: 159 (species list), 171 (species description, synonyms); Mayer 1917: 189 (species description), 230 (key); Stiasny 1919: 48 (remarks to systematics of Carybdeidae); Light 1921: 26, 28 (species lists), 29 (species record); Krumbach 1925: 564 (general morphology of order Carybdeida, species mentioned as an example for anatomically primitive forms); Mayer 1928: 175 (species list of the "Albatross" Expedition), 189 (species description, measurements-Fig. 3 is not Carybdea grandis); Bigelow 1938: 145 (synonyms to Carybdea alata, citation of Mayer (1915)), 146 (citation of Mayer (1915, 1917)); Kramp 1961: 304, 305 (size variation to $C$. alata, synonyms to $C$. alata), 306 (synonyms to Tamoya gargantua), 449 (index) ; Gershwin 2005a: 143 (in synonyms to Alatina moseri)

Carybdea alata grandis: Williamson et al. 1996: 241 (species list "large carybdeidas"), 242-243 (observations, species description)

Carybdea cf. grandis: Gershwin 2003: 157 (species list of Guam);

Carybdea grandis: Mayer 1910: 508 ("a variety of C. alata); Mayer 1915: 171 (synonyms to Carybdea alata var. grandis); Stiasny 1919: 37 (comparison with Carybdea alata var. moseri), 38 (citation Mayer (1906, 1910), comparison with Carybdea alata var. moseri), 45 (discussion Tamoya bursaria), 48, 51, 52 (remarks to systematics of Carybdeidae, footnote), 53 (distribution/habitat); Krumbach 1925: 570 (mentioned in discussion on systematic classification); Bigelow 1938: 138-139 (grouping of species, foot note), 145 (history); Coates 2003: 544 (locality, habitat); Gershwin 2003: 157 (species list of Guam); Gershwin 2005a: 3 (mentioned in introduction), 129 (mentioned in introduction to Alatina chapter [5]), 142 (in synonyms to Alatina moseri), 152 (mentioned); Gershwin, 2005b: 501 (mentioned in introduction), 513 (in synonyms to Alatina moseri), 516 (mentioned), 520 (in discussion of Alatina clade)

Carybdea marsupialis: Kazmi \& Sultana 2008: 1-2 (throughout, first record in Gwadar (Arabian Sea), description of examined material, Figs. $1+2$ habitus and velarial canals); Gul et al. 2015: 3 (discussion of erroneous identification), 6 (Table 1, species list).

Charybdea alata: Stiasny 1939: 18-20 (specimen from Kamaran (Red Sea), description, Figs. 1-4: habitus, rhopalial niche, gastric filament, quadrant of velarium);

Charybdea alata var. grandis: Thiel 1936: 287 (comparison species lists of Haeckel (1880) and Mayer (1910)), 289 (citation Mayer (1910)); Coates 2003: 543 (Table 1: summary of cubozoan species with reported habitats);

Charybdea grandis: Agassiz \& Mayer 1902: 153-154 (description), 174 (plate explanations), 176 (species list), plate 6, figs. 26-31; Mayer 1910: 511 (synonyms to Carybdea alata var. grandis); Mayer 1915: 171 (synonym to Carybdea alata var. 
grandis); Mayer 1917: 189 (synonym to Carybdea alata var. grandis); Bigelow 1909: 19-20 (relationship to C. moseri discussed); Stiasny, 1919: 38 (synonyms to Tamoya bursaria); Thiel 1928: 2 (species list), 3 (introduction), 4-5 (species sample description); Thiel 1936: 266 (anatomy and biology), 270 (life span), 272, 284 (citation of Agassiz \& Mayer (1902)), 285 (distribution; citation Bigelow (1909)), 287 (comparison species lists of Haeckel (1880) and Mayer (1910)), 288 (citation of Stiasny (without year)), 289 (citation of Stiasny (1919)), 290 (species list of Stiasny (1919)), 291 (citation of Krumbach (1925)); Kramp 1961: 304, 305 (synonyms to C. alata), 449 (index); Coates 2003: 543 (Table 1: summary of cubozoan species with reported habitats);

Tamoya alata: Stiasny 1937: 203, 204 (species list of John Murray Expedition and systematics), 210-213 (systematics, sampling locations, measurements, detailed species description; animals caught in depth of 984-430 m with self-closing net).

Tamoya gargantua: Kramp 1956: 237-239 (localities, description of specimens collected in Iranian Gulf; map).

\section{Description}

Bell (Fig. 1A), in-life, highly transparent, colourless; distal end of pedalia, orange to reddish brown coloured; gastric phacellae, pinkish to yellowish pink (Fig. 1D); tentacles, same colour as gastric phacellae; bell covered with large, raised nematocyst warts (Fig. 3C); truncate, coneto torpedo-shaped, higher than wide: $240 \mathrm{~mm}(\mathrm{BH}$; mean: $200 \mathrm{~mm}$, range: $180->240 \mathrm{~mm}, \mathrm{n}=10$ ), $140 \mathrm{~mm}$ (IPD; mean: $122 \mathrm{~mm}$; range: $114-140 \mathrm{~mm}, \mathrm{n}=10$ ), apex, blunt to plane convex; mesoglea thick in-life (Figs. 1A, 3A, H, K, $\mathrm{L})$ but can become very weak when preserved in low concentration formalin (Figs. 1C, 4A, F); no horizontal constriction near top.

Rhopalial niches, 4; orifice "T"-shaped (Figs. 1F, G, 3D, M, 4D, J) with 1 upper covering scale, oval; lower covering scales, 2, very long with vertical opposed edges; ca. 1/6 of bell height up from margin. Rhopalium with 6 eyes ( 2 median lens eyes, 2 lateral pit, 2 lateral slit eyes).

Pedalia (Figs. 1J, K, 3F, N, 4C, H), 4, single, short in length (length 1/5-1/4 of BH), slightly stalked (stalk length ca. 1/3 of PL), flattened, broad leaf-shaped; inner and outer wings both well "over-hanging" tentacle insertion (Figs. $1 \mathrm{C}, \mathrm{K}, 3 \mathrm{~F}, \mathrm{~N}, 4 \mathrm{C}, \mathrm{H}$ ); inner wing slightly broader than outer wing; pedalial canal knee bend dome to volcano-shaped with broad, blunt, rounded top (Figs. 1H, I, 4C, I); pedalial canals characteristic in shape (Figs. 1J, K, 3F, M), broad from canal knee bend downwards, after first pedalium-half tapering towards distal end; tentacles, 4, round in cross section, very thin and delicate in comparison to body size (Figs. 1A, B, 3A, 4F).

Velarium, broad, more than $1 / 3$ of bell diameter; velarial canal roots, 3 per octant (Figs. 1L, M, 2A); velarial canals, 1-3 per root, broad at base, tapering towards distal end, straight, all more or less equally complex: simple to tri-forked with additional bi-forked tips, many short, spike-like side canals and lobes giving jagged appearance, rounded tips; canals flanking frenulum, 1; middle canals, 1; canals flanking pedalia, 2-3 (Fig. 1L, M); adradial lappets, 3 per octant, covering bases of canal roots.

Manubrium, very short (1/5 of $\mathrm{BH})$, four-lobed; stomach, flat, shallow; gastric phacellae, 4, two winged, crescent-shaped (Figs. 1D, E, 3B, I, 4B, G), on four stomach corners, gastric filaments, numerous, multiple rooted, long-stemmed, brush-shaped (Fig. 3J).

Gonads, slender leaf-shaped, reaching from stomach to bell turnover (Fig. 3A).

\section{Type material:}

HOLOTYPE: USA: National Museum of Natural History (USNM), Washington: 1 specimen (USNM 42114), French Polynesia, at the water surface off Anaa Island in the Tuamotu Archipelago (Paumotu Islands at the time) on board the steamer Albatross on 15 October 1899, A. G. Mayer (Bentlage 2010)

\section{Additional material:}

Pakistan: Museum of the Department of Zoology, Jamia Milla Government Degree College (JMGDC), Karachi: 6 mature specimens (JMGDC MDZ CN 22), Pakistan, off Sonmiani $\left(25^{\circ} 25^{\prime} 21.873^{\prime \prime} \mathrm{N}, 6^{\circ} 35^{\prime} 53.864^{\prime \prime} \mathrm{E}\right)$, collected by Shawanaz Gul, 26 February 2015.

Material labelled as Carybdea grandis:

United Kingdom: British Natural History Museum, London (BNHM): 1 immature specimen, good condition (BNHM 1983.4.25.2: BH $140 \mathrm{~mm}$, IPD $87 \mathrm{~mm}$, PDL: $50 \mathrm{~mm}$ ), The Philippine Islands, collected by Prof. F. Nemenco, April 1955.

Material labelled as Tamoya alata:

United Kingdom: British Natural History Museum, London (BNHM): 3 specimens from the 'John Murray' Expedition 1933-34 from the Arabian Sea and adjacent seas: 1 male, intact, very good condition (BNHM 1950.3.25.1: BH: $240 \mathrm{~mm}$, IPD: $140 \mathrm{~mm}$, PDL: $55 \mathrm{~mm}$ ), Arabian Sea, St. $43\left(17^{\circ} 48^{\prime} 3^{\prime \prime}\right.$ N, 55 $\left.5^{\circ} 8^{\prime} 3^{\prime \prime} \mathrm{E}\right)$, near Kuria Muria, surface, sampled with handnet, 28 Oct 1933; 1 animal without gonads, broken into pieces due to size (1950.3.25.2: PDL: $95 \mathrm{~mm})$, Gulf of Oman, St. 65 $\left(25^{\circ} 2^{\prime} 12^{\prime \prime} \mathrm{N}, 59^{\circ} 40^{\prime} 30^{\prime \prime} \mathrm{E}\right)$, came on hydrographer's wire above water bottle, 21 Nov 1933; 1 animal with developing gonads, good condition, (1950.3.25.3: BH: $180 \mathrm{~mm}$, IPD: $100 \mathrm{~mm}$, PDL: $52 \mathrm{~mm})$, Central Arabian Sea, St. $95\left(12^{\circ} 08^{\prime} 06^{\prime \prime} \mathrm{N}, 63^{\circ} 04^{\prime} 36^{\prime \prime}\right.$ to $\left.12^{\circ} 05^{\prime} 18^{\prime \prime} \mathrm{N}, 63^{\circ} 01^{\prime} 42 \mathrm{E}\right), 2$ metre townet, $1400 \mathrm{~m}$ wind out, $18 \mathrm{Dec} 1933$.

Material labelled as $C$. cf. grandis or C. grandis:

Germany: Zoologisches Museum der Universität Hamburg (ZMH): Saipan, ZSMH uncatalogued, 1928, M.E. Thiel (Gershwin 2003). USA: Museum of Comparative Zoology, Harvard (MCZ): 2 non-type specimens (MCZ1043, MCZ342), Pacific Ocean, Society Islands, coll. A. Gar- 
rett, 29 September 1861; originally preserved in alcohol, now preserved in formalin, identified by Bigelow (1909, p. 20) (Gershwin 2005b)

\section{Type locality:}

Anaa Island, Tuamotu Archipelago, French Polynesia

\section{Distribution of Alatina grandis according to literature records and our data}

French Polynesia: Tuamotu Archipelago: The Tuamotu and Gambier Islands, off Fakarava Atoll $\left(16^{\circ} 03^{\prime} 05^{\prime \prime} \mathrm{S}\right.$, $\left.145^{\circ} 39^{\prime} 31^{\prime \prime} \mathrm{W}\right)$ and off Anaa Island $\left(17^{\circ} 20^{\prime} 31^{\prime \prime} \mathrm{S}\right.$, $\left.145^{\circ} 30^{\prime} 31^{\prime \prime} \mathrm{W}\right)$ (Agassiz \& Mayer 1902; Bentlage 2010)

Malaysia: Borneo, Tawau, Sabah ("off Mount Putri"), Celebes Sea $\left(4^{\circ} 22^{\prime} 86^{\prime \prime} \mathrm{N}, 117^{\circ} 96^{\prime} 79^{\prime \prime} \mathrm{E}\right)$ (Mayer 1928)

The Philippines: Manila Bay, Luzon $\left(14^{\circ} 31^{\prime} \mathrm{N}, 120^{\circ} 46^{\prime} \mathrm{E}\right)$ (Mayer 1928; present study)

Somalia: East of Cape Guardafui, central area of Arabian Sea, John Murray Expedition Stations $172\left(9^{\circ} 40^{\prime} 24^{\prime \prime} \mathrm{N}\right.$, $54^{\circ} 33^{\prime} 36^{\prime \prime} \mathrm{E}$ to $\left.9^{\circ} 42^{\prime} 18^{\prime \prime} \mathrm{N}, \quad 9^{\circ} 42^{\prime} 18^{\prime \prime} \mathrm{N}, \quad 54^{\circ} 39^{\prime} 00^{\prime \prime} \mathrm{E}\right)$ (Sewell 1935, Stiasny 1937, present study)

Oman: near Khuriya Muriya Islands, John Murray Expedition Station $43\left(17^{\circ} 48^{\prime} 3^{\prime \prime} \mathrm{N}, 55^{\circ} 78^{\prime} 3^{\prime \prime} \mathrm{E}\right)$ (Sewell 1935, Stiasny 1937 , present study)

Iran: Gulf of Oman, John Murray Expedition Station 65 $\left(25^{\circ} 2^{\prime} 12^{\prime \prime} \mathrm{N}, 5^{\circ} 40^{\prime} 30^{\prime \prime} \mathrm{E}\right)$ (Sewell 1935, Stiasny 1937, present study)

Yemen: South end of Red Sea, Kamaran, $\left(15^{\circ} 21^{\prime} 0^{\prime \prime} \mathrm{N}\right.$, $42^{\circ} 34^{\prime} 0^{\prime \prime}$ E) (Stiasny 1939)

Pakistan: Gwadar, fish harbor (Kazmi \& Sultana 2008); off Karachi $\left(24^{\circ} 51^{\prime} 41.264^{\prime \prime} \mathrm{N}, 67^{\circ} 0^{\prime} 35.779^{\prime \prime} \mathrm{E}\right)$ and off Sonmiani $\left(25^{\circ} 25^{\prime} 21.873^{\prime \prime} \mathrm{N}, 66^{\circ} 35^{\prime} 53.864^{\prime \prime}\right)$ (present study).

Arabian Sea: Central area of Arabian Sea, John Murray Expedition Stations $95\left(12^{\circ} 08^{\prime} 06^{\prime \prime} \mathrm{N}, 63^{\circ} 04^{\prime} 36^{\prime \prime}\right.$ to $12^{\circ} 05^{\prime} 18^{\prime \prime} \mathrm{N}, 63^{\circ} 01^{\prime} 42 \mathrm{E}$ ) (Sewell 1935, Stiasny 1937)

\section{Acknowledgements}

We would like to thank some anonymous fisherman who photographed a living Karachi specimen sampled in 2014 and Mr. Muhammad Moazzam Khan (WWF-Pakistan, 46K, Block 6, PECHS, Karachi 75400, Pakistan) who provided this image by forwarding it to the $2^{\text {nd }}$ author. Special thanks to Dr. André C. Morandini (Universidade de São Paulo, Brazil) for his diplomatic ways that helped to connect different worlds and for commenting on a draft version of this paper. ISP would like to thank Miranda Lowe (Principal Curatorand Collections Manager, The Natural History Museum, London) who made my first visit to the museum possible after short notice, her friendly welcome and her help in all matters concerning the collection during both of her visits. The first author received for this research support from the SYNTHESYS Project (GBTAF-6151) http://www.synthesys.info/ which is financed by the European Community Research Infrastructure Action under FP7 Integrating Activities Programme.
Additionally, we would like to thank two anonymous reviewers and Dr. Dhugal Lindsay for their constructive advice.

\section{References}

Acevedo M, Straehler-Pohl I, Morandini AC, Stampar SN, Bentlage B, Matsumoto GI, Yanagihara A, Toshino S, Fuentes V (in review) Revision and redescription of the genus Carybdea (Cnidaria: Cubozoa) due to a case of numerous species being united under the same name-Carybdea marsupialis. Zootaxa.

Agassiz A, Mayer AG (1902) Reports on the scientific results of the expedition to the tropical Pacific, in charge of Alexander Agassiz, by the U.S. Fish Commission steamer "Albatross", from August, 1899, to March, 1900, Commander Jefferson F. Moser, U.S.N., Commanding III. Medusae. Mem Mus Comp Zoölogy Harv Coll 26(3): 139-176.

Bentlage B (2010) Carybdea alata auct. (Cubozoa): rediscovery of the Alatina grandis type. Zootaxa 2713: 52-54.

Bentlage B, Lewis C (2012) An illustrated key and synopsis of the families and genera of carybdeida box jellyfishes (Cnidaria: Cubozoa: Carybdeidaa), with emphasis on the "Irukandji family” (Carukiidae). J Nat Hist 46(41-42): 2595-2620.

Bentlage B, Cartwright P, Yanagihara AA, Lewis C, Richards GS, Collins AG (2010) Evolution of box jellyfish (Cnidaria: Cubozoa), a group of highly toxic invertebrates. Proc R Soc B 277: 493-501. http://dx.doi.org/10.1098/rspb.2009.1707

Bigelow HB (1909) Reports on the scientific results of the expedition to the eastern tropical Pacific, in charge of Alexander Agassiz, by the U.S. Fish Commission Steamer "Albatross" from Oct. 1904 to March 1905, Lieut. Commander L.M. Garrett, U.S.N., commanding, XVI. The Medusae. Mem Mus Comp Zoölogy Harv Coll 37: 1-243.

Bigelow HB (1938) Plankton of the Bermuda Oceanographic Expeditions VIII. 5. Medusae taken during the Years 1929 and 1930. Zoologica 23(5): 99-180.

Bordehore C, Fuentes V, Atienza D, Barberá C, Fernandez-Jover D, Roig M, Acevedo-Dudley M, Canepa AJ, Gili J-M (2011) Detection of an unusual presence of the cubozoan Carybdea marsupialis at shallow beaches located near Denia, Spain (south-western Mediterranean). Mar Biodivers Rec 4(e69): 1-6. doi: 10.1017/S1755267211000650

Bordehore C, Nogué S, Gili J-M, Acevedo, MJ, Fuentes VL (2014) Carybdea marsupialis (Cubozoa) in the Mediterranean Sea: The first case of a sting causing cutaneous and systemic manifestations. J Travel Med 22(1): 61-63. DOI: 10.1111/ jtm. 12153

Bowers GM (1909) The United States Fisheries Steamer "Albatross" and her work. Advance print of the Proceedings of the Seventh International Zoological Congress, Boston Meeting, August 19-24, 1907. Harvard MCZ: 1-4.

Campbell RD (1974) Cnidaria. In: Reproduction of marine invertebrates. Vol. I. Acoelomate and pseudocoelomate metazoans (eds Giese AC, Pearse JS). Academic Press, pp. 133-199.

Canepa A, Purcell JE, Belmar MB, Acevedo M, Gentile M, Fuentes V (2014) Salinity effects on asexual reproduction of 
Carybdea sp. (Cnidaria: Cubozoa). J Plankton Res 36(2): 585590. doi: 10.1093/plankt/fbt124

Carrette T, Seymour J (2004) A rapid and repeatable method for venom extraction from Cubozoan nematocysts. Toxicon 44: $135-139$.

Carrette T, Seymour J (2005) Vascular dopplers: a new way of recording cardiac parameters in envenomed organisms. Toxicon 45: 541-544.

Carrette T, Seymour J (2006) Cardiotoxic effects of venoms from Chironex fleckeri and Chiropsalmus sp. on an invertebrate model. J Venom Anim Toxins incl Trop Dis 12(2): 246.

Carrette, T. \& Seymour, J. (2013) Long-term analysis of Irukandji stings in Far North Queensland. Diving Hyperb Med 43(1): 9-15.

Carrette T, Alderslade P, Seymour J (2002) Nematocyst ratio and prey in two Australian cubomedusans, Chironex fleckeri and Chiropsalmus sp. Toxicon 40: 1547-1551.

Carrette T, Straehler-Pohl I, Seymour J (2014) Early life history of Alatina cf. moseri populations from Australia and Hawaii with implications for taxonomy (Cubozoa: Carybdeida, Alatinidae). PLoS ONE 9(1): e84377 doi: 10.1371/journal. pone. 0084377

Carrette TJ, Underwood AH, Seymour JE (2012) Irukandji syndrome: a widely misunderstood and poorly researched tropical marine envenoming. Diving Hyperb Med 42(4): 214-223.

Chiaverano LM, Holland BS, Crow GL, Blair L, Yanagihara AA (2013) Long-term fluctuations in circalunar beach aggregations of the box jellyfish Alatina moseri in Hawaii, with links to environmental variability. PLoS ONE 8(10): 1-10: e77039. doi: 10.1371/journal.pone.0077039

Coates MM (2003) Visual ecology and functional morphology of Cubozoa (Cnidaria). Integr Comp Biol 43: 542-548.

Collins AG, Bentlage B, Gillan WB, Lynn TH, Morandini AC \& Marques AC (2011) Naming the Bonaire banded box jelly, Tamoya ohboya, n. sp. (Cnidaria: Cubozoa: Carybdeida: Tamoyidae). Zootaxa 2753: 53-68.

Conant FS (1897) Notes on the Cubomedusae. JHUC 132: 8-10.

Cornelius PFS (1997) Class Scyphozoa-jellyfish. In: A guide to the seashores of eastern Africa and the western Indian Ocean islands (ed Richmond MD). SIDA/Department for Research Cooperation, SAREC, pp. 122-125.

Fenner PJ, Fitzpatrick PF, Hartwick R, Skinner R (1985) “Morbakka”-Another Cubomedusan. Med J Aust 143: 550-555.

Fenner PJ (1986) The Morbakka, another species of box jellyfish. SPUMS J 16(3): 118-119.

Garm A, Bielecki J (2008) Swim pacemakers in box jellyfish are modulated by the visual input. J Comp Physiol A 194: 641-651. DOI: 10.1007/s00359-008-0336-0

Garm A, Ekström P, Boudes M, Nilsson D-E (2006) Rhopalia are integrated parts of the central nervous system in box jellyfish. Cell Tissue Res 325: 333-343.

Garm A, Coates MM, Gad R, Seymour J, Nilsson D-E (2007a) The lens eyes of the box jellyfish Tripedalia cystophora and Chiropsalmus sp. are slow and color-blind. J Comp Physiol A: 1-11. DOI: 10.1007/s00359-007-0211-4

Garm A, O'Connor M, Parkefelt L, Nilsson D-E (2007b) Visually guided obstacle avoidance in the box jellyfish Tripedalia cystophora and Chiropsella bronzie. J Exp Biol 210: 3616-3623.
Garm A, Lebouvier M, Tolunay D (2015) Mating in the box jellyfish Copula sivickisi-Novel Function of Cnidocytes. J Morphol 276(9): 1055-1064. DOI: 10.1002/jmor.20395

Garm A, Andersson F, Nilsson D-E (2008) Unique structure and optics of the lesser eyes of the box jellyfish Tripedalia cystophora. Vision Res 48: 1061-1073.

Garm A, Bielecki J, Petie R, Nilsson D-E (2012) Opposite patterns of diurnal activity in the box jellyfish Tripedalia cystophora and Copula sivickisi. Biol Bull 222: 35-45.

Gershwin L (2003) Scyphozoa and Cubozoa of Guam. Micronesica 35/36: 156-158.

Gershwin L (2005a) Taxonomy and phylogeny of Australian Cubozoa. PhD Thesis. School of Marine Biology and Aquaculture, James Cook University, 202 pp.

Gershwin L (2005b) Carybdea alata auct. and Manokia stiasnyi, reclassification to a new family with description of a new genus and two new species. Mem Queensl Mus 51(2): 501-523.

Gershwin, L-A (2006) Comments on Chiropsalmus (Cnidaria: Cubozoa: Chirodropida): a preliminary revision of the Chiropsalmidae, with descriptions of two new genera and two new species. Zootaxa 1231, 1-42.

Gershwin L (2007) Malo kingi: A new species of Irukandji jellyfish (Cnidaria: Cubozoa: Carybdeida), possibly lethal to humans, from Queensland, Australia. Zootaxa 1659, 55-68.

Gershwin L (2008) Morbakka fenneri, a new genus and species of Irukandji jellyfish (Cnidaria: Cubozoa). Mem Queensl Mus Nat 54(1): 23-33.

Gershwin L (2014) Two new species of box jellies (Cnidaria: Cubozoa: Carybdeida) from the central coast of Western Australia, both presumed to cause Irukandji syndrome. Rec West Aust Mus 29(1): 10-19.

Gershwin L, Alderslade P (2005) A new genus and species of box jellyfish (Cubozoa: Carybdeidae) from tropical Australian waters. Rec West Aust Mus 21: 27-36.

Gershwin L, Gibbons MJ (2009) Carybdea branchi, sp. nov., a new box jellyfish (Cnidaria: Cubozoa) from South Africa. Zootaxa 2088: 41-50.

Gueroun SKM, Acevedo MJ, Kéfi-Daly Yahia O, Deidun A, Fuentes VL, Piraino S, Daly Yahia MN (2015) First records of Carybdea marsupialis proliferation (Cnidaria: Cubozoa) along the eastern Tunisian coast (Central Mediterranean). Ital J Zool 82(3): 430-435. DOI: 10.1080/11250003.2015.1045945

Gul S, Morandini AC, Häussermann V, Pörschmann U (2015) Checklist of cnidarians from Pakistani waters. CheckList 11(2): 1609: 1-8. doi: http://dx.doi.org/10.15560/11.2.1609.

Haacke W (1887) Die Scyphomedusen des St. Vincent Golfes. Jenaische Naturwiss Zeitschrift 20: 588-638.

Haeckel E (1880) System der Acraspeden. Zweite Hälfte des Systems der Medusen. Denkschriften der MedizinischNaturwissenschaftlichen Gesellschaft zu Jena 2: 361-672.

Haeckel E (1904/1998) Kunstformen der Natur: mit beschreibendem Text, allgemeiner Erläuterung und systematischer Übersicht. Neudruck der Erstausgabe des Bibliographisches Instituts in Leipzig und Wien, 1904, Prestel-Verlag, München, New York, $280 \mathrm{pp}$.

Kazmi QB, Sultana R (2008) Carybdea marsupialis (Cnidaria: Cubomedusae)-observed for the first time in Gwadar Bay waters (Arabian Sea). Mar Biodivers Rec 1(e80): 1-2. doi: 


\section{$10.1017 / \mathrm{S} 1755267207008251$}

Kingsford MJ, Mooney CJ (2014) Chapter 12: The Ecology of Box Jellyfishes (Cubozoa). In: Jellyfish Blooms (eds Pitt KA, Lucas CH). Springer Science+Business Media Dordrecht, pp. 267-302. DOI: 10.1007/978-94-007-7015-7 12

Kingsford MJ, Seymour JE, O’Callaghan MD (2012) Abundance patterns of cubozoans on and near the Great Barrier Reef. Hydrobiologia 690: 257-268. DOI: 10.1007/s10750-012-1041-0

Kishinouye K (1891) Zwei neue Medusen von Charybdea (Ch. brevipedalia n.sp., Ch. latigenitalia n.sp.). Zool Soc Jap 3: 3645.

Kishinouye K (1910) Some medusae of Japanese waters. J Coll Sci Imp Univ Tokyo 27(9): 2-35.

Kramp PL (1956) Medusae of the Iranian Gulf. Vidensk Medd fra Dansk naturh Foren 118: 235-242.

Kramp PL (1961) Synopsis of the medusae of the world. J Mar Biol Assoc UK 40: 304-310.

Krumbach T (1925) Scyphozoa. In: Handbuch der Zoologie (eds Kükenthal W, Krumbach T). W. de Gruyer, Berlin, pp. 522686.

Lewis C, Long TAF (2005) Courtship and reproduction in $\mathrm{Ca}$ rybdea sivickisi (Cnidaria: Cubozoa). Mar Biol 147: 477-483.

Lewis C, Kubota S, Migotto AE, Collins AG (2008) Sexually dimorphic cubomedusa Carybdea sivickisi (Cnidaria: Cubozoa) in Seto, Wakayama. Publ Seto Mar Biol Lab 40(5/6): 1-8.

Lewis C, Bentlage B, Yanagihara AA, Gillan W, van Blerk J, Keil DP, Bely AE, Collins AG (2013) Redescription of Alatina alata (Reynaud, 1830) (Cnidaria: Cubozoa) from Bonaire, Dutch Caribbean. Zootaxa 3737(4): 473-487.

Lesson R-P (1843) Histoire Naturelle des ZoophytesAcalèphes. Librairie Encyclopédique de Roret, Paris, 596 pp.

Light SF (1921) Further notes on philippine scyphomedusan jellyfishes. Philippine J Sci 18: 25-45.

Maas O (1897) XXI. Die Medusen-Reports on an exploration off the West Coasts of Mexico, Central and South America, and off the Galapagos Islands, in charge of Alexander Agassiz, by the U.S. Fish Comission Steamer "Albatross" during 1891, Lieutenant Commander Z. L. Tanner, U.S.N., Commanding. Mem Mus Comp Zoöl Harvard Coll 23(1): 1-92.

Marques AC, Collins AG (2004) Cladistic analysis of Medusozoa and cnidarian evolution. Invertebr Biol 123: 23-42. http:// dx.doi.org/10.1111/j.1744-7410.2004.tb00139.x

Mayer AG (1906) Medusae of the Hawaiian Islands collected by the Steamer Albatross in 1902. Fish Bull 3: 1131-1143.

Mayer AG (1910) The medusae of the world. Volume III. The scyphomedusae. Carnegie Inst Wash Publ 109 III: 499-735.

Mayer AG (1915) VII. Medusae of the Philippines and of Torres Straits-Report upon the Scyphomedusae collected by the United States Fisheries Bureau Steamer "Albatross" in the Philippine Islands and Malay Archipelago, 1907-1910, and upon medusae collected by the expedition of the Carnegie Institution of Washington to Torres Straits, Australia, in 1913. Pap Dep Mar Biol Carnegie Inst Wash 8: 157-202.

Mayer AG (1917) Report upon the Scyphomedusae collected by the U.S. Bureau of Fisheries steamer "Albatross" in the Philippine Islands and Malay Archipelago. Bull 100 1(3): 171-233.

Mayer AG (1928) Report upon the Scyphomedusae collected by the United States Fisheries Bureau Steamer “Albatross” in the
Philippine Islands and Malay Archipelago-Contributions to the Biology of the Philippine Archipelago and adjacent regions-Papers on the collections gathered by the "Albatross" Philippine Expedition 1907-1910. Bull 100 1: 175-234.

Menon MGK (1930) The Scyphomedusae of Madras and the neighbouring coast. Bull Madras Govt Mus-Nat Hist Ser 3(1): $1-28$.

Moore SJ (1988) A new species of cubomedusan (Cubozoa: Cnidaria) from Northern Australia. The Beagle, Records of the Northern Territory Museum of Arts and Sciences 5(1), 1-4.

Morandini AC, Marques AC (2010) Revision of the genus Chrysaora Péron \& Lesueur, 1810 (Cnidaria: Scyphozoa). Zootaxa 2464: 1-97.

Müller F (1859) Zwei neue Quallen von Santa Catharina (Brasilien). Abh Naturwiss Ges Halle 5: 1-12.

Nilsson D-E, Gislén L, Coates MM, Shogh C, Garm A (2005) Advanced optics in a jellyfish eye. Nature 435: 201-205.

Nordström K, Wallén R, Seymour J, Nilsson D (2003) A simple visual system without neurons in jellyfish larvae. Proc R Soc Lond, Ser B 270: 2349-2354.

Pagès F, Gili J-M, Bouillon J (1992) Medusae (Hydrozoa, Scyphozoa, Cubozoa) of the Benguela Current (southeastern Atlantic). Mar Sci 56(1): 1-64.

Péron F, Lesueur CA (1810) Histoire générale et particulière tous les animaux qui composent la famille des Meduses. Annals Mus Hist Nat 14: 312-66.

Petersen KW (1979) Development of coloniality in Hydrozoa. In: Biology and systematics of colonial animals (eds Larwood G, Rosen BR). Academic Press, NewYork, pp. 105-139.

Reynaud AAM (1830) La Carybdée (Méduse) ailée. Carybdea alata $\mathrm{n}$. sp. In: Centurie Zoologique (ed Lesson RP). FG Levrault, Paris, Brussels, p. 95, Plate 33.

Sewell RBS (1935) Introduction and list of Stations, The John Murray Expedition, 1933-34. Rep Br Ass Advmt Sci I: 1-41.

Southcott RV (1967) Revision of some Carybdeidae (Scyphozoa: Cubomedusae), including a description of the jellyfish responsible for the 'Irukandji' Syndrome. Aust J Zool 15: 651-671.

Stiasny G (1919) VI.-Die Scyphomedusen-Sammlung des Naturhistorischen Reichsmuseums in Leiden, 1. Die Carybdeidaen (Cubomedusen). Zool Medd 5: 33-58.

Stiasny G (1926) Üeber einige Scyphomedusen von Puerto Galera, Mindoro (Philippinen). Zool Medd 9: 239-248.

Stiasny G (1930) Scyphomedusen. In: Résultats scientifiques du Voyage aux Indes Orientales Néderlandaises. Mém Mus $r$ his nat Belg (Hors Serie) 2(4): 1-12.

Stiasny G (1937) Scyphomedusae. John Murray Expedition 1933-1934. Sci Rep 4: 203-242.

Stiasny G (1939) Über einige Scyphomedusen von Kamaran (Rotes Meer). Zool Anz 128(1/2): 17-23.

Straehler-Pohl I (2014) Critical evaluation of characters for species identification in the cubomedusa genus Malo (Cnidaria, Cubozoa, Carybdeida, Carukiidae). Plank Benth Res 9(2): 83-98.

Straehler-Pohl I, Jarms G (2011). Morphology and life cycle of Carybdea morandinii, sp. nov. (Cnidaria), a cubozoan with zooxanthellae and peculiar polyp anatomy. Zootaxa 2755: 36-56.

Straehler-Pohl I, Toshino S (2015) Carybdea morandinii-New investigations on its life cycle reveal its true genus: Carybdea 
morandinii Straehler-Pohl \& Jarms, 2011 becomes Alatina morandinii (Straehler-Pohl \& Jarms, 2011) Plank Benth Res 10(4): $1-11$.

Straehler-Pohl I, Garm A, Morandini AC (2014) Sexual dimorphism in Tripedaliidae (Conant 1897) (Cnidaria, Cubozoa, Carybdeida). Zootaxa 3785(4): 533-549.

Thiel ME (1928) Die Scyphomedusen des Zoologischen StaatsInstitut und Zoologischen Museums in Hamburg. 1. Cubomedusen, Stauromedusen und Coronatae. Mitt Zool Mus Hamburg 43: 1-34.

Thiel ME (1936) Cubomedusae. In: Dr. HG. Bronns Klassen und Ordnungen des Tierreichs. Zweiter Band: Spongiaria, Coefenterata, Echinodermata, 11. Abteilung: Coelenterata, 2. Buch Scyphomedusae, 2. Lieferung. Akademische Verlagsgesellschaft mbH, Leipzig, pp. 173-308.

Toshino S, Miyake H, Otsuka S, Okuizumi K, Adachi A, Hamatsu Y, Urata M, Nakaguchi K, Yamaguchi S (2013) Development and polyp formation of the giant box jellyfish Morbakka virulenta (Kishinouye, 1910) (Cnidaria: Cubozoa) collected from the Seto Inland Sea, western Japan. Plank Benth Res
8(1): $1-8$.

Toshino S, Miyake H, Ohtsukab S, Adachi A, Kondo Y, Okada S, Hirabayashi T, Hiratsuka T (2015) Monodisc strobilation in Japanese giant box jellyfish Morbakka virulenta (Kishinouye, 1910): A strong implication of phylogenetic similarity between Cubozoa and Scyphozoa. Evol Dev 17(4): 231-239.

Verrill, AE (1865) Classification of polyps: (extract condensed from a synopsis of the Polypi of the North Pacific Exploring Expedition, under Captains Ringgold and Rodgers, U.S.N.). Proc Essex Inst 4: 145-152.

Werner B (1973) New investigations on systematics and evolution of the class Scyphozoa and the phylum Cnidaria. Publ Seto Mar Biol Lab 20: 35-61.

Williamson J, Fenner P, Burnett JW (1996) Venomous and poisonous marine animals. University of New South Wales Press, Sydney, 504 pp.

Yanagihara A-A, Kuroiwa JMY, Oliver LM, Chung JJ, Kunkel DD (2002) Ultrastructure of a novel eurytele nematocyst of Carybdea alata Reynaud (Cubozoa, Cnidaria). Cell Tissue Res 308: 307-318. DOI: 10.1007/s00441-002-0545-8. 